\title{
PENGARUH PEMBERIAN SUPLEMEN TEPUNG TEMULAWAK (Curcuma xanthorrhiza Roxb) TERHADAP KONSUMSI PROTEIN KASAR, KECERNAAN PROTEIN KASAR DAN PRODUKSI PROTEIN SUSU PADA SAPI PERAH LAKTASI
}

\section{Effect of Curcuma Flour (Curcuma xanthorrhiza Roxb) Supplement on Crude Protein Consumption, Crude Protein Digestibility and Milk Protein Production in Lactation Dairy Cows}

\author{
Dedy Setiadi*, Rudy Hartanto, Dian Wahyu Harjanti \\ Faculty of Animal and Agricultural Sciences, University of Diponegoro \\ Kompleks Drh. R. Soejono Koesoemowardojo, Tembalang, Kec. Tembalang, Kota Semarang, \\ Jawa Tengah 50275 \\ *E-mail : dedysetiadi2012@gmail.com \\ Submitted : June 29, $2020 \quad$ Accepted : November 29, 2020
}

\begin{abstract}
ABSTRAK
Penelitian ini bertujuan untuk mengetahui pengaruh pemberian suplemen tepung temulawak (Curcuma xanthorriza Roxb) terhadap konsumsi PK dan produksi protein susu sapi perah laktasi. Materi yang digunakan adalah 12 ekor sapi perah Friesian Holstein $(\mathrm{FH})$ dengan pengelompokan berdasarkan produksi susu yang ada di KTT Wahyu Agung, Getasan. Rancangan percobaan yang digunakan adalah rancangan acak kelompok (RAK) dengan 2 perlakuan dan 6 kelompok berdasarkan produksi susu. Perlakuan yang diterapkan yaitu $\mathrm{T} 0=$ sebagai kontrol, $\mathrm{T} 1=$ suplemen temulawak $1 \%$ kebutuhan BK. Parameter yang diamati meliputi jumlah konsumsi protein kasar pakan, kecernaan protein kasar dan produksi protein susu. Data dianalisis menggunakan analisis ragam taraf signifikan $5 \%$. Hasil penelitian menunjukkan bahwa rataan konsumsi protein kasar T0 sebesar 1,589 kg/ekor/hari, T1 sebesar 1,599 $\mathrm{kg} / \mathrm{ekor} / \mathrm{hari}$, kecernaan protein kasar T0 sebesar 72,70\%, T1 sebesar 75,68\% dan produksi protein susu T0 sebesar 0,210 kg/ekor/hari, T1 sebesar 0,205 kg/ekor/hari. Hal tersebut menunjukkan pemberian suplemen tepung temulawak 1\% kebutuhan BK tidak berpengaruh nyata terhadap konsumsi protein kasar, kecernaan protein kasar dan produksi protein susu. Kesimpulan penelitian adalah penambahan suplemen temulawak sebanyak 1\% kebutuhan BK belum mampu meningkatkan konsumsi protein kasar, kecernaan protein kasar dan produksi protein susu sapi perah laktasi.
\end{abstract}

Kata kunci: Kecernaan, Konsumsi, Protein kasar, Protein susu, Temulawak.

\section{ABSTRACT}

This study aims to determine the effect of curcuma flour (Curcuma xanthorriza Roxb) supplement on crude protein consumption and protein production of lactating dairy cow's milk. The material used was 12 Friesian Holstein (FH) dairy cows with grouping based on milk production at the KTT Wahyu Agung, Getasan. The experimental design used a randomized block design (RCBD) with 2 treatments and 6 groups. The treatment applied is $T O=$ as a control, $T 1=$ curcumar supplement $1 \%$ based on dry material requirements. The parameters observed included the amount of crude protein consumption of feed, crude protein digestibility and milk protein production. The data obtained were analyzed using analysis of varians with significance levels of 5\%. The results showed that the treatment was not significantly affecting the parameters. The average consumption of crude protein of T0 was $1.589 \mathrm{~kg} / \mathrm{head} / \mathrm{day}$, T1 was 1.599 $\mathrm{kg} / \mathrm{head} /$ day, digestibility of crude protein of T0 was $72.70 \%, \mathrm{Tl}$ was $75.68 \%$ and milk protein production of T0 was $0.210 \mathrm{~kg} / \mathrm{head} /$ day, T1 was $0.205 \mathrm{~kg} / \mathrm{head} /$ day. It was concludedthat thesuplementation of $1 \%$ curcuma flour based on dry material requirements has not been able to increase consumption of crude protein, digestibility of crude protein and protein production of lactating dairy cow's milk

Keywords: Consumption, Crude protein, Curcuma, Digestibility, Milk protein. 


\section{PENDAHULUAN}

Sapi perah merupakan salah satu jenis ternak yang dimanfaatkan sebagai penghasil susu di Indonesia. Menurut Pusat Data dan Sistem Informasi Pertanian (2018) jumlah produksi susu sapi perah di Indonesia tahun 2017 adalah 0,92 juta ton/tahun. Susu segar yang kualitasnya baik mengandung komposisi berupakadar lemak minimum 3,0\%, bahan kering tanpa lemak minimum 7,8\%, protein minimum 2,8\% (Badan Standarisasi Nasional, 2011). Presentase masingmasing komposisi nutrien dalam susu tidak selalu stabil tetapi sering mengalami perubahan karena beberapa faktor yaitu tingkat konsumsi pakan, kandungan nutrien pada bahan pakan yang diberikan, genetik dan lingkungan(McDonald et al., 2011).

Konsumsi pakan merupakan sejumlah pakan yang dapat dikonsumsi ternak pada periode waktu tertentu, dan merupakan faktor penting yang akan menentukan aras, fungsi, dan respon ternak serta penggunaan nutrien yang ada pada pakan (Van Soest, 1994). Jumlah konsumsi pakan (biasanya diukur dalam bahan kering (BK)) merupakan salah satu tanda terbaik dari produktivitas ternak dan juga faktor esensial yang menjadi dasar untuk hidup dan menentukan produksi (NRC, 2001). Protein kasar (PK) merupakan bagaian dari BK, sehingga konsumsi PK diketahui dari konsumsi pakan, yang dihitung dengan cara mengalikan konsumsi BK dengan kadar protein pakan (Rahardjo, 2010).

Kecernaan (digestibility) didasarkan pada asumsi bahwa zat makanan yang tidak terdapat dalam feses merupakan zat yang tercerna dan terabsorbsi (Tillman et al, 1998). Kecernaan menjadi tinggi rendahnya nilai nutrisi dari suatu bahan pakan. Ternak ruminansia memiliki kelebihan dalam mencerna serat kasar tinggi, karena terdapat mikroba dalam rumen. Kelancaran proses pencernaan didalam rumen bergantung pada ketersediaan zat-zat makanan yang akan bertindak sebagai prekursor bagi kerja enzim-enzim pencernaan (Laryska dan Nurhajati, 2013). Kecernaan PK mencerminkan seberapa besar protein kasar dari pakan yang dapat dimanfaatkan oleh ternak. Sintesis protein dalam rumen memerlukan pasokan asam amino dalam jumlah yang seimbang, pasokan protein berkualitas tinggi dan tahan terhadap degradasi rumen (Santosa et al, 2009). Tinggi rendahnya konsumsi PK dan kecernaan PK pada ternak ruminansia sangat dipengaruhi oleh faktor-faktor eksternal (lingkungan), faktor internal (kondisi ternak itu sendiri) dan pakan yang diberikan (Silva et al, 2016).
Salah satu faktor yang mempengaruhi protein susu adalah protein pakan yang terkonsumsi dan banyaknya protein kasar yang tercerna akan diubah menjadi asam amino (Rajcevic et al.,2003). Protein susu disintesis menggunakan asam amino sebagai bahan baku utamanya, dan asam amino tersebut diperoleh melalui penyerapan asam amino di usus halus. Salah satu tujuan utama pemberian pakan ternak adalah memaksimalkan jumlah asam amino yang tersedia di usus halus untuk diserap masuk ke tubuh ternak (Silva et al, 2016), yang dapat berasal dari protein mikroba dan protein pakan yang tidak terdegradasi oleh rumen.Asam-asam amino yang diserap oleh dinding usus halus dan dibawa oleh darah menuju ke hati, selanjutnya oleh darah disalurkan ke jaringan tubuh salah satunya kelenjar susu untuk membentuk protein susu (McDonald et al., 2011).

Temulawak (Curcuma xanthorrhiza Roxb) dapat dimanfaatkan sebagai penambah nafsu makan alami karena mengandung senyawan kurkumin, minyak atsiri dan flavonoid yang bersifat antimikrobial terhadap beberapa mikroorganisme (Dicky dan Apriliana, 2016). Kandungan kurkumin pada temulawak berfungsi untuk meningkatkan nafsu makan, memperlancar sekresi cairan empedu dan pankreas, mengemulsi lemak, membantu absorbsi lemak dan vitamin larut dalam lemak, sehingga aktivitas pencernaan meningkat. Minyak atsiri mampu meningkatkan nafsu makan karena minyak mampu bekerja mempercepat pengosongan lambung sehingga cepat menimbulkan rasa lapar (Rahardjo, 2010).

Temulawak digunakan sebagai bahan pakan tambahan yang bertujuan meningkatkan nafsu makan pada ternak sapi perah. Sehingga konsumsi protein kasar dan kecernaan protein kasar meningkat seiring dengan meningkatnya nafsu makan ternak, yang berdampak pada peningkatan produksi protein susu sapi perah laktasi. Kandungan kurkumin dan minyak atsiri dapat meningkatkan populasi mikroba rumen yang menguntungkan dan meningkatkan konsumsi ransum (Sulistyowati, 2008). Suplementasi temulawak yang mengandung kurkuminoid $(3,16 \%)$ dan minyak atsiri $(15,5 \%)$ per $100 \mathrm{~g}$ bahan kering akan memperbaiki keseimbangan mikroba rumen sehingga terjadi peningkatan efisiensi metabolisme, abosorbsi nutrisi dan mensintesisnya menjadi susu dan lemak susu (Indriani et al, 2013). Oleh karena itu diperlukan adanya eksplorasi terhadap temulawak sebagai alternatif suplemen pakan yang dapat meningkatkan konsumsi protein kasar, kecernaan protein kasar dan produksi protein susu sapi perah laktasi. 
Penelitian ini bertujuan mengkaji pengaruh pemberian suplemen herbal berupa temulawak terhadap konsumsi PK, kecernaan PK dan produksi protein susu sapi perah laktasi. Manfaat penelitian dapat memberikan informasi terkait meningkatkan produksi protein susu sapi laktasi menggunakan suplemen herbal. Hipotesis dari penelitian yaitu temulawak yang diberikan sebagai suplemen dapat meningkatkan konsumsi PK, kecernaan PK dan produksi protein susu sapi perah laktasi.

\section{MATERI DAN METODE}

Penelitian dilaksanakan pada tanggal 23 Januari - 24 Februari 2019 di KTT (Kelompok Tani Ternak) Wahyu Agung Dusun Bumiharjo, Desa Sumogawe, Kecamatan Getasan, Kabupaten Semarang. Analisis sampel pakan dilakukan di Laboratorium Ilmu Nutrisi dan Pakan, analisis kadar protein susu dilakukan di Laboratorium Produksi Ternak Potong dan Perah, Fakultas Peternakan dan Pertanian, Universitas Diponegoro.

\section{Materi}

Materi yang digunakan dalam penelitan yaitu 12 ekor sapi perah betina Friesian Holstein (FH) bobot badan 461,57 $\pm 44,99 \mathrm{~kg}(\mathrm{CV}: 9,75 \%)$ dan produksi susu 6,87 $\pm 2,70$ L/hari (CV:39,34\%), periode laktasi ke 4-3 dan bulan laktasi 5-6, tepung temulawak, susu serta ransum yang terdiri dari hijauan berupa rumput gajah dan konsentrat.Peralatan yang digunakan yaitu: pita ukur untukmengukur bobot badan ternak, timbangan analitik untuk menimbang suplemen pakan, botol susu, cooling box, lactoscan untuk mengetahui komposisi dalam susu, timbangan gantung, karung plastik, timbangan pakan dan alat tulis.

\section{Metode}

Metode penelitian meliputi empat langkah yaitu rancangan penelitian, langkah pra penelitian, langkah perlakuan dan pengambilan data serta dilanjutkan dengan langkah analisis data.

Percobaan dilakukan berdasarkan rancangan acak kelompok (RAK) yang terdiri dari 2 perlakuan dengan 6 kelompok (Tabel 6). Pengelompokan berdasarkan produksi susu yang dihasilkan dengan cara menghitung rata-rata produksi susu perhari selama 30 hari sebelum penelitian dilakukan. Perlakuan yang diberikan terdiri dari: $\mathrm{T} 0=$ pakan basal , dan $=\mathrm{T} 1$ pakan basal + suplementasi $1 \%$ kebutuhan BK berdasarkan $3 \%$ bobot badan.

\section{Prosedur Penelitian}

Langkah persiapan meliputi pengumpulan bahan tepung temulawak, dan suplemen pakan. Pemberian suplemen temulawak kepada ternak berdasarkan $1 \%$ kebutuhan BK pakan (3\% dari bobot badan). Tahap adaptasi dilakukan dilakukan selama 1 minggu di awal periode dengan cara sapi yang telah masuk kriteria dilakukan pemberian suplemen dengan tujuan agar sapi terbiasa mengkonsumsi ransumyang diberi tambahan suplemen temulawak.

Penelitian menggunakan pakan yang berupa hijauan, konsentrat komersil dan komboran (pakan tambahan). Pemberian pakan mengikuti jadwal yang sudah berjalan di KTT Wahyu Agung. Hijauan terdiri atas campuran rumput gajah dan tebon (tanaman jagung) sebanyak $30 \mathrm{~kg}$ dengan perbandingan 50 : 50 ,setiap pemberian masing-masing $15 \mathrm{~kg}$ yang diberikan setelah pemerahan pagi dan sore. Komboran I sebanyak $6 \mathrm{~kg}$ tiap pemberiansaat sebelum dan setelah pemerahan pagi dan sore. Konsentrat (WA Feed) sebanyak $2 \mathrm{~kg}$ tiap pemberian dicampurkan dengan suplemen temulawak sebagai perlakuan yang diberikan sebelum pemerahan pagi dan sore. Komboran II yang diberikan setelah pemerahan pagi dan sore hari sebanyak $3 \mathrm{~kg}$ tiap pemberian. Kandungan nutrien dalam masing-masing bahan pakan disajikan dalam Tabel 1 dan jumlah pemberian tepung temulawak pada T1 disajikan dalam Tabel 2.

\section{Perlakuan dan Pengambilan Data}

Perlakuan dilakukan selama 30 hari dengan tahap pengambilan data meliputi pengambilan jumlah produksi susu dan konsumsi pakan yang dilakukan selama 30 hari selama penelitian berlangsung. Pengambilan sampel susu pada hari ke 30 sebanyak $250 \mathrm{ml}$ pagi dan $250 \mathrm{ml}$ sore hari disimpan dalam cooling box kemudian sampel pagi dan sore hari dihomogenkan terlebih dahulu sebelum dianalisis,untuk mengetahui kandungan dan produksi protein susu. Sampel pakan dari bahan pakan segar dan sisa pakan dilakukan analisis proksimat untuk mengetahui kandungan protein kasar pakan.

Konsumsi Pakan diukur dengan menghitung selisih antara pakan yang diberikan dikurangi dengan pakan sisa. Pengukuran konsumsi pakan dilakukan setiap hari selama penelitian pada masing-masing sapi yang digunakan. Pakan yang diberikan dan sisa pakan (tidak dilakukan kontrol pelayuan) dilakukan pengambilan sampel yang kemudian dilanjutkan dengan analisis bahan kering untuk memperoleh data bahan kering pakan dan bahan kering sisa 
pakan. Perhitungan konsumsi bertujuan untuk mengetahui konsumsi Bahan Kering (BK).

Konsumsi BK =

[pakan pemberian $\mathrm{x} \%$ BK pakan pemberian] [sisa pakan $\mathrm{x} \%$ BK sisa pakan]

Kecernaan protein kasar pakan dihitung dengan mengetahui jumlah konsumsi protein kasar terlebih dahulu kemudian dikurangi dengan protein feses total dengan dilakukan total koleksi selama 5 hari pada tanggal 19 sampai dengan 24 Februari 2019. Total koleksi feses yang dilakukan berguna utuk mengetahui protein kasar feses yang terbuang sehingga dapat diketaui protein kasar yang terserap. Rumus menghitung kecernaan protein kasar adalah sebagai berikut.

Konsumsi $\mathrm{PK}=\%$ PK pakan $\times$ konsumsi BK $(\mathrm{kg})$

$\mathrm{PK}$ Feses $=\%$ PK feses $\times$ BK feses $(\mathrm{kg})$

Kecernaan PK =

$$
\frac{\sum \text { Konsumsi PK }-\sum \text { PK Feses }}{\sum \text { Konsumsi PK }} \times 100 \%
$$

Produksi susu, produksi susu diperoleh dengan cara mencatat hasil pemerahan sapi perah laktasi yang digunakan dalam penelitian setiap pagi dan sore. Pengukuran dilakukan selama penelitian yaitu 30 hari. Pengukuran produksi susu dilakukan dengan menggunakan gelas ukur berskala. Hasil produksi susu dihitung menggunakan rumus untuk memperoleh jumlah produksi dalam satu masa laktasi. Pengukuran produksi susu dalam satu masa laktasi dihitungmenurut Murti (2014) dengan rumus sebagai berikut :

Produksi susu dalam satu masa laktasi

$$
=\frac{100 \%}{\% \text { Bulan Laktasi }} \times \frac{30}{30} \times \text { produksi susu total }
$$

Keterangan \% bulan laktasi : bulan $1(12 \%)$, bulan $2(13 \%)$, bulan $3(12 \%)$, bulan $4(12 \%)$, bulan 5 $(11 \%)$, bulan $6(10 \%)$, bulan $7(9 \%)$, bulan 8 $(8 \%)$, bulan $9(7 \%)$, bulan $10(6 \%)$.

Analisis berat jenis (BJ) susu dan kadar protein susu diuji dengan Lactoscan, kemudian dilakukan perhitungan produksi protein susu dengan menggunakan rumus :

Produksi susu $(\mathrm{kg})=$

Produksi susu (liter) $\times$ BJ susu $(\mathrm{kg} / \mathrm{l})$
Protein protein susu $(\mathrm{kg})$ $=\%$ Protein susu $\times$ produksi susu $(\mathrm{kg})$

\section{HASIL DAN PEMBAHASAN}

\section{Pengaruh Perlakuan Terhadap Konsumsi Protein Kasar}

Analisis ragam menunjukkan bahwa perlakuan suplemen temulawak $1 \%$ BK pakan memberikan pengaruh yang tidak nyata $(\mathrm{P}>0,05)$ terhadap konsumsi PK sapi perah laktasi (Tabel 3). Artinya perlakuan tersebut tidak menyebabkan perbedaan konsumsi PK secara signifikan. Hal tersebut dapat dilihat pada rata-rata konsumsi PK T0 sebesar 1,59 kg/hari dan T1 sebesar 1,60 kg/hari.

Kandungan senyawa aktif dari perlakuan suplemen temulawak sebanyak $1 \%$ kebutuhan BK belum mampu meningkatkan konsumsi PK dan hasil tidak jauh berbeda dengan T0 yaitu kontrol. Hal ini terjadi diduga karena suplementasi juga tidak meningkatkan konsumsi BK. Hasil dari tim penelitian Kharisa (2019) menunjukkan bahwa penambahan temulawak sebesar $1 \%$ kebutuhan BK belum mampu meningkatkan konsumsi BK pakan sapi perah laktasi yaitu rata-rata konsumsi BK T0 sebesar 18,0607 kg BK sedangkan T1 sebesar $18,1895 \mathrm{~kg}$ BK. Sukardi (2005) menyatakan bahwa konsumsi PK sejalan dengan konsumsi BK dan kadar ransum PK, sehingga peningkat konsumsi BK akan meningkatkan konsumsi PK. Selain di pengaruhi oleh konsumsi BK, tingkat konsumsi PK yang sama tersebut juga dipengaruhi kandungan protein kasar ransum relatif sama. sehingga menghasilkan konsumsi PK yang sama pula. Menurut Widyobroto et al (2008) bahwa terdapat respon positif antara konsumsi bahan kering dan konsumsi protein kasar.

Beberapa penelitian terhadap hewan percobaan telah dibuktikan bahwa pemberian suplemen temulawak dapat meningkatkan nafsu makan dan memberikan dampak positif terhadap pankreas diantaranya dapat mempengaruhi dan merangsang sekresi getah pankreas, mempengaruhi kontraksi dan tonus usus halus, membantu kerja sistem hormonal, metabolisme dan fisiologi organ tubuh (McDonald et al, 2011). Kandungan kurkumin dan desmetoksikurkumin pada temulawak berfungsi untuk meningkatkan nafsu makan dengan memperlancar sekresi empedu dan memperbaiki keseimbangan mikroba rumen sehingga terjadi peningkatan efisiensi metabolisme (Rahardjo, 2010). Mikroba yang tidak terpengaruh oleh flavonoid dan minyak atsiri dalam rumen yang semakin meningkat akan menyebabkan peningkatan pada proses fermentasi dalam rumen yang menghasilkan jumlah VFA (volatile fatty acids) semakin tinggi. Menurut Lucy et al. (2017) 
yang menyatakan bahwa percepatan pengosongan lambung dan peningkatan nafsu makan pada ternak ruminansia disebabkan adanya produksi VFA yang semakin tinggi karena pakan yang terdegradasi dalam rumen semakin cepat.

Jika fungsi diatas berjalan dengan baik maka seharusnya suplementasi temulawak dapat meningkatkan konsumsi BK. Namun dalam penelitian ini suplemen temulawak $1 \%$ belum meningkatkan fungsi tersebut secara optimal. Hal ini dikarenakan perlakuan tunggal sementara penelitian yang lain dikombinasikan dengan bahan lain agar fungsi temulawak bekerja dengan maksimal dengan adanya supplementary effect. Komponen dari temulawak yang akan bekerja supplementary effect yaitu minya atsiri dan kurkumin. Penelitian lain menunjukkan temulawak $0,5 \%$ dari kebutuhan BK yang dikombinasikan dengan tape singkong mengakibatkan peningkatan konsumsi BK pakan pada sapi perah laktasi(Sulistyowati et al., 2010). Penelitian yang lain dengan pemberian suplemen temulawak lebih banyak yaitu $2 \%$ kebutuhan BK pakan dikombinasikan dengan seng proteinat mampu meningkatkan konsumsi bahan kering sapi perah laktasi (Indriani et al., 2013). Temulawak dengan kadar pemberian 1,5\% yang dikombinasikan dengan ragi dapat meningkatkan aktivitas mikroba rumen sehingga akan meningkatkan proses pencernaan dalam rumen (Sulistyowati et al, 2015). Pemberian temulawak yang dikombinasikan dengan lengkuas berpengaruh nyata terhadap produksi protein susu sapi perah (Harjanti et al, 2019). Jadi hasil penelitian ini menunjukkan bahwa penggunaan suplemen $1 \%$ dari kebutuhan BK pakan belum cukup optimal jika diberikan secara tunggal, sehingga peningkatan konsumsi pakan juga belum optimal.

\section{Pengaruh Perlakuan Terhadap Kecernaan Protein Kasar}

Analisis ragam menunjukkan bahwa perlakuan suplemen temulawak $1 \%$ BK pakan memberikan pengaruh yang tidak nyata $(\mathrm{P}>0,05)$ terhadap kecernaan PK sapi perah laktasi (Tabel 4).Artinya perlakuan tersebut tidak menyebabkan perbedaan kecernaan PK secara signifikan, walaupun cenderung naik. Hal tersebut dapat dilihat pada rata-rata kecernaan PK T0 sebesar $72,70 \%$ dan $\mathrm{T} 1$ sebesar $75,68 \%$ dengan nilai kecernaan tersebut belum mampu menunjukkan pengaruh yang nyata. Namun nilai kecernaan protein tersebut belum cukup baik dibandingkan dengan kecernaan protein ransum pada sapi perah secara umumnya yaitu sebesar 74,0379,87\% (Cahyono et al., 2015). Hasil penelitian ini berbeda dengan Sulistyowati et al. (2008) yang menyatakan bahwa dengan perlakuan modifikasi ransum yang mengandung konsentrat laktasi (KL) dengan temulawak $15 \mathrm{~g} / \mathrm{kg} \mathrm{KL}$ menghasilkan konsumsi PK yang berkisar 1,28$1,38 \mathrm{~kg} /$ ekor/hari setara dengan $16,5 \%$ dari BK ransum pada masing masing level dan menghasilkan kecernaan protein kasar sebesar $78,58-80,97 \%$ dibanding tanpa temulawak sebesar 66,99-72,27\% yang artinya mampu meningkatkan kecernaan protein kasar .

Kandungan senyawa aktif dari perlakuan suplemen temulawak sebesar $1 \%$ kebutuhan BK belum mampu meningkatkan kecernaan PK. Hal ini sejalan dengan hasil dari tim penelitian Prihantoro(2019) yang menunjukkan bahwa perlakuan suplemen temulawak sebesar $1 \%$ kebutuhan $\mathrm{BK}$ belum mampu meningkatkan kecernaan bahan kering (KcBK) dan kecernaan bahan organik (Kc BO), dimana KcBK T0 yaitu kontrol sebesar $60,88 \%$ dan $\mathrm{T} 1$ yaitu perlakuan sebesar 59,20\% sedangkan KcBO T0 sebesar $57,46 \%$ dan $\mathrm{T} 1$ sebesar 55,59\%, nilai tersebut tidak menunjukkan pengaruh nyata. Selain itu hasil kecernaan PK ini sejalan dengan konsumsi BK, BO dan PK. Hal ini disebabkan adanya hubungan positif antara konsumsi PK dengan konsumsi BK dan BO sesuai yang dikemukakan oleh Widyobroto et al. (2008) bahwa konsumsi bahan kering mempunyai respon positif terhadap konsumsi protein dan produksi susu pada sapi perah. Menurut Susanti dan Marhaeniyanto (2007), kecernaan sangat tergantung pada komposisi zat makanan yang terkandung dalam pakan dan laju aliran pakan meninggalkan rumen. Hal ini diduga karena konsumsi PK yang tidak berbeda nyata menyebabkan kecernaan PK tidak mengalami peningkatan secara signifikan karena penggunaan zat makanan dan komposisi pakan dalam penelitian ini relatif sama. Hal ini didukung oleh pendapat Damry, (2008) yang menyatakan bahwa, semakin tinggi aras PK ransum maka palatabilitas pakan dan kecernaan pakan juga meningkat. Jadi peningkatan kecernaan dapat dilihat dari peningkatan konsumsi pakan.

Kecernaan PK yang tidak berbeda nyata berakibat terhadap asam amino yang terserap tidak mengalami peningkatan secara signifikan. Hal tersebut menyebabkan substrat yang digunakan untuk produksi protein susu tidak mengalami peningkatan. Padahal sintesis protein susu berasal dari asam amino yang beredar dalam darah sebagai hasil penyerapan saluran pencernaan (Milas dan Marenjak, 2007).

Susanti dan Marhaeniyanto (2007) menyatakan bahwa protein pakan yang tercerna digunakan untuk meningkatkan kualitas susu yaitu protein 
susu. Protein pakan yang terdapat dalam rumen mengalami proteolisis oleh enzim mikroba menjadi oligopeptida dan asam amino. Sebagian asam amino didegradasikan menjadi amonia $\left(\mathrm{NH}_{3}\right)$ kemudian akan digunakan untuk mensintesis protein mikroba. Menurut Krisnawan (2017), proses sintesis mikroba yang meningkat mampu menambah populasi mikroba rumen, sehingga proses fermentasi pakan oleh mikroba dapat meningkat dan jika mikroba mati maka protein mikroba beserta protein pakan yang lolos degradasi akan menjadi sumber asam amino saat sintesis protein susu.

\section{Pengaruh Perlakuan Terhadap Produksi Protein Susu}

Analisis ragam menunjukkan bahwa perlakuan suplemen temulawak $1 \%$ BK pakan memberikan pengaruh yang tidak nyata $(\mathrm{P}>0,05)$ terhadap produksi protein susu harian dari sapi perah laktasi, dan fenomena ini tetap sama ketika data produksi protein susu disetarakan ke dalam 1 masa laktasi(Tabel 5).Artinya perlakuan tersebut tidak menyebabkan perbedaan produksi protein susu secara signifikan. Hal tersebut dapat dilihat pada rata-rata produksi protein susu T0 sebesar 0,210 kg/ekor/hari dan T1 sebesar 0,205 kg/ekor/hari. Produksi protein susu akibat perlakuan suplemen temulawak 1\% BK pakan tidak berpengaruh nyata disebabkan oleh temulawak dengan taraf pemberian $1 \%$ BK pakan belum mampu meningkatkan palatabilitas pakan, sehingga tidak dapat meningkatkan konsumsi BK pakan dan tidak menunjukkan pengaruh nyata terhadap produksi susu sapi perah laktasi. Selain itu juga dikarenakan konsumsi protein dan kecernaan protein dari hasil penelitian yang tidak berbeda. Nilai produksi protein susu 0,205-0,210 $\mathrm{kg} /$ hari ini lebih rendah dari penelitian Indriani et al. (2013) yang menggunakan Zn proteinat dan suplemen temulawak sebanyak $2 \%$ kebutuhan BK pakan mampu menghasilkan produksi protein susu 0,268-0,324 kg/hari. Dalam hal ini protein lebih banyak dimanfaatkan untuk zat pembangun dan pengganti sel yang rusak, sehingga protein yang disintesis dalam kelenjar ambing lebih sedikit.

Prihatminingsih et al. (2015) menyatakan bahwa kandungan protein susu dipengaruhi oleh banyaknya protein pakan serta kualitas protein pakan yang dikonsumsi, semakin banyak asam amino dalam darah dari degradasi protein maka semakin banyak juga prekursor protein susu. Hubungan antara konsumsi PK dan produksi protein susu menunjukkan hubungan linier yang positif yang artinya semakin tinggi konsumsi PK maka semakin tinggi pula kadar protein
susu.Konsumsi protein dan kecernaan protein yang tidak berbeda menyebabkan produksi protein susu juga tidak berbeda. Dapat diketahui bahwa hasil konsumsi PK akibat perlakuan suplementasi temulawak $1 \%$ kebutuhan BK tidak menunjukkan pengaruh yang nyata. Hal tersebut berpengaruh terhadap prekursor protein yang diserap dalam tubuh, sehingga menyebabkan produksi protein susu yang tidak mengalami peningkatan.

Sintesis protein susu berasal dari asam amino yang beredar dalam darah sebagai hasil penyerapan saluran pencernaan maupun hasil perombakan protein tubuh dan asam amino yang disintesis oleh sel epitel kelenjar susu. Menurut Milas dan Marenjak (2007), asam amino yang diserap merupakan sumbangan protein mikroba rumen yang mencapai $40-80 \%$ dan sisanya protein endogenus atau protein bypass.

\section{SIMPULAN}

Penambahan suplemen tepung temulawak (Curcuma xanthorriza Roxb) sebanyak 1\% kebutuhan BK belum mampu meningkatkan konsumsi protein kasar pakan, kecernaan protein kasar pakan dan produksi protein susu sapi perah laktasi.

\section{DAFTAR PUSTAKA}

Anggorodi, R. 1995. Nutrisi Aneka Ternak. Gramedia Pustaka Utama. Jakarta.

Astuti, A., A. Agus, S.P.S. Budhi. 2009. Pengaruh penggunaan high quality feed suplemen terhadap konsumsi dan kecernaan nutrien sapi perah awal laktasi. Buletin Peternakan, 33(2): 81 - 87.

Badan Standardisasi Nasional. 2011. SNI Nomor 3141-2011 - Tentang Syarat Mutu Susu Segar. Badan Standardisasi Nasional. Jakarta.

Cahyono, B, D., Sulistyowati, E dan I, Badarini. 2015. Kecernaan nutrisi konsentrat PUFA yang Mengandung Curmiyeast pada sapi perah laktasi. J. Sain Peternakan Indonesia. 10: 59-70.

Damry. 2008. Landasan Biologis Upaya Pemenuhan Kebutuhan Protein Ternak Ruminansia. Prosiding Seminar Nasional Sapi Potong. Fakultas Peternakan Universitas Tadulako. Palu. Hal. 108-115.

Dicky, A. dan E. Apriliana. 2016. Efek pemberian ekstrak temulawak (Curcuma xanthorrhiza Roxb) terhadap daya hambat pertumbuhan Staphylococcus aureus dan 
escherichia coli secara In Vitro. $J$. Kedokteran Unila. 1(2): 308 - 312.

Harjanti, D. W., F. Wahyono, D.N. Afifah. 2019. Milk production and milk quality of subclinical mastitis cows feed with different supplementation of herbal in the diet. IOP Conf. Series: Earth and Environmental Science. 250: 012062

Indriani, A. P., A. Muktiani dan E. Pangestu. 2013. Konsumsi dan produksi protein susu sapi perah laktasi yang diberi suplemen Temulawak (Curcuma xanthorriza) dan Seng Proteinat. Anim. Agric. J. 2 (1): 128 -135 .

Kharisa, N. E. 2019. Konsumsi pakan dan produksi susu sapi perah laktasi penderita mastitis subklinis yang diberi suplemen dan treatment antiseptik teat dipping temulawak (Curcumua xanthorriza Roxb). Fakultas Peternakan dan Pertanian, Universitas Diponegoro, Semarang. (Skripsi).

Krisnawan. 2017. Pengaruh imbangan hijauan dengan konsentrat dan suplementasi urea yang berbeda pada sapi laktasi terhadap konsumsi protein, kecernaan protein dan protein susu. Fakultas Peternakan dan Pertanian,Universitas Diponegoro, Semarang. (Skripsi).

Laryska, N. dan T. Nurhajati. 2013. Peningkatan kadar lemak susu sapi perah dengan pemberian pakan konsentrat komersial dibandingkan dengan ampas tahu. J. Agro Veteriner. 1(2): $79-87$.

Lucy, J., L. Florencia, Elvina, D. Stefani, A.I. Susanti. 2017. Efek pemberian Temulawak terhadap berat badan dan sistem imun Mencit BALB/c. J. Sains dan Teknologi. 1(1): $32-50$.

McDonald, P., R. A. Edwards and J. F. D.Greenhalgh, C. A. Morgan, L. A. Sinclair and R. G. Wilkinson. 2011. Animal nutrition. $7^{\text {th }}$ Ed. Pearson Education. Harlow.

Milas, N. P. and Marenjak, T. S. 2007. Monitoring of milk production and total cholesterol concentration, gamma-glutamyltransferase, and glutathione peroxidise in Simmental Cows Blood. J. Mljekarstvo. 57(2): $89-100$.

Murti, T.W. 2014. Ilmu Manajemen dan Industri Ternak Perah. Pustaka Reka Cipta. Bandung.

NRC. 2001. Nutrient Requirement of Dairy Cattle. $8^{\text {th }}$ Edition. National Academic of Science. Washington D.C.
Prihantoro, Y. P. 2019. Konsumsi total digestible nutrient, kecernaan bahan kering dan bahan organnik sapi perah laktasi yang mendapatkan suplemen tepung temulawak (Curcuma xanthorriza Roxb). Skripsi. Fakultas Peternakan dan Pertanian, Universitas Diponegoro. Semarang.

Prihatminingsih, E. G., Purnomoadi, A., D.W. Harjanti. 2015. Hubungan antara konsumsi protein dengan produksi, protein dan laktosa susu kambing Peternakan Etawa. $J$. Ilmu-Ilmu Peternakan. 25(2): 20 - 27.

Pusat Data dan Sistem Informasi Pertanian. 2018. Outlook 2018 : Komoditas Pertanian Subsektor Pertanian, Susu. Pusat Data dan Sistem Informasi Pertanian, Sekretariat Jenderal, Kementerian Pertanian. Jakarta.

Rahardjo, M. 2010. Penerapan SOP budidaya untuk mendukung temulawak sebagai bahan baku obat potensial. Perspektif 9(2): $78-93$.

Rajcevic, M., K. Potocnik, J. Levstek. 2003. Correlations between somatic cells count and milk composition with regard to the season. J. Agriculturae Conspectus Scientificus. 68 (3): 221 - 226.

Santosa, K. A., K. Dwiyanto, T. Toharmat. 2009. Profile Usaha Peternakan Sapi Perah di Indonesia. LIPI Press. Jakarta.

Silva, V.N., A.H.N. Rangel, J.G.B. Galvão Júnior, S.A. Urbano , L.H.F. Borba, L.P. Novaes, D.M. Lima Júnior. 2016. Influence of somatic cell count in the composition of girolando cow's milk in tropical zone. Tropical and Subtropical Agroecosystems. 19(2): $101-107$.

Sulistyowati, E., U. Santoso, I. Badarina, E. Sutrisno dan T. Saputra. 2008. Modification of Temulawak (Curcuma xanthorriza Roxb) Levels of Tabut Block on Milk Production of FH Cows. Proceeding : Management for Achievement of Millenium Development Goals. Pp. 20-26.

Sulistyowati, E., I. Badarina dan U. Santoso. 2010. Suplementasi level temulawak (Curcuma xanthorrhiza Roxb) yang berbeda dalam konsentrat pada sapi Frisien Holland laktasi terhadap total digestible nutrient (TDN) ransum. J. Sains Peternakan Indonesia. 5(1): 20-26.

Sulistyowati, E., I. Badarani, S. Mujiharjo, A. Rusman, B.D. Cahyono, Sistanto. 2015. Curmiyeast as supplement in pufa concentrate fot modifying production and quality of dairy cow milk in Bengkulu. Proceeding : Internasional Seminar on 
Promoting Local Resources for food and Health. Pp. 115-118.

Sukardi. 2005. Metabolisme Protein Pakan dan Laju Penurunan Produksi Susu Akibat Pemberian Sauropus androgynus Merr (Katu) pada Ransum Sapi Perah Friesian Holstein (FH). Tesis, Program Pasca Sarjana Universitas Diponegoro. Semarang.

Susanti, S. dan Marhaeniyanto, E. 2007. Kecernaan, retensi nitrogen dan hubungannya dengan produksi susu pada sapi Peranakan Fiesian Holstein (PFH) yang diberi pakan pollard dan bekatul. $J$. Ilmiah Ilmu-Ilmu Peternakan. 15(2): 141148.
Tillman, A. D., Hartadi, S. Prawirokusumo, S. Reksohadiprodjo dan S. Lebdosukojo. 1998. Ilmu Makanan Ternak Dasar. Cetakan ke-5. Gadjah Mada University Press. Yogyakarta.

Van Soest, P. J. 1994. Nutritional Ecology of The Ruminant. $2^{\text {nd }} \mathrm{Ed}$. Comstock Publishing Associates A Division of Cornell Uniersity Press. Ithaca and London.

Widyobroto, B. P., Budhi, S. P. S. dan Agus. A. 2008. Pengaruh aras undegraded protein dan energy terhadap intake dan kecernaan nutrient serta metabolism darah Pada Sapi Perah. J. Animal Production, 10(2): 96101 